Економічні науки: збірник наукових праџь Луцького національного технічного університету. - Серія "Регіональна економіка". - Випуск 15 (59). - Редкол.: відп. ред. д.е.н., професор Л.Л. Ковальська. - Луиьк: ІВВ Луиького НТУ, 2018. - 292 с.

УДК 338.435

Купира М.І.. к.е.н., старший викладач

Грибук Р.М., студент

Луцький національний технічний університет

\title{
ІМПЕРАТИВИ ПОКРАЩЕННЯ ФІНАНСОВИХ РЕЗУЛЬТАТІВ ДІЯЛЬНОСТІ ПІДПРИЄМСТВА В СИСТЕМІ ІННОВАЦІЙНОГО РОЗВИТКУ
}

У статті розглянуто та систематизовано категорії «прибуток» та «збиток» 3 подальшим визначенням суті фінансових результатів. Обгрунтовано, що метою фінансових результатів підприємства $\epsilon$ пошук імперативів збільшення прибутку, як основного фінансового результату діяльності, використовуючи інноваційні засоби в напрямку його нарощення.

Тобто, ефективне управління формуванням та використанням фінансових результатів підприємства дасть змогу забезпечити зростання достатку власників підприємства як фундаментальної основи фінансового менеджменту, що проявляється в зростанні вартості підприємства та створенні прибуткового результату.

Ключові слова: фінансові результати, прибуток, збиток, рентабельність, інноваційні засоби.

Kupyra M.I. Grybuk R.M.

\section{IMPERATIVES IMPROVEMENT FINANCIAL RESULTS OF THE ENTERPRISE ACTIVITY IN THE SYSTEM OF INNOVATION DEVELOPMENT}

The categories are considered and systematized «gain» and «loss» with subsequent determination of essence of financial results in the article. Grounded, that the purpose of financial results of enterprise is a search of imperatives of increase of income, as a basic financial result of activity, using innovative facilities in direction of his increase.

As a result of research essence of financial results the characteristic features of two components are selected: to gain and loss, that stopped up in this concept. Consequently, under the financial results of activity of enterprise will understand a quantitative total score, source of economic facilities, which characterizes comparison of regulated the legislations of gross receipts and gross charges of represented in form income or loss of enterprise.

Based on offered approach near the estimation of financial results of activity of enterprise in the system will mortgage innovative facilities for the improvement 
Економічні науки: збірник наукових праџь Луцького національного технічного університету. - Серія "Регіональна економіка". - Випуск 15 (59). - Редкол.: відп. ред. д.е.н., професор Л.Л. Ковальська. - Луцьк: ІВВ Луиького НТУ, 2018. - 292 с.

of financial results and receipt of maximally effective result. In the algorithm of improvement of financial results of enterprise mortgage the use of modern methods of raising of knowledge of population innovative facilities in relation to making of products of mass consumption and promotion of it in the points of retail business.

It should be noted that it is suggested to use all increase of gross receipt from introduction of the offered measures and part of own resources of enterprise on creation of the unique service of marketing. However much it costs to consider general growth of competitiveness and strengthening of competition positions at the market, got as a result of the correct going near organization and leadthrough financially economic to activity of enterprise the most substantial result of introduction of the noted measures.

Keywords: financial results, profit, loss, profitability, innovative means.

Купира М.И., Грибук Р.М.

\section{ИМПЕРАТИВЫ УЛУЧШЕНИЯ ФИНАНСОВЫХ РЕЗУЛЬТАТОВ ДЕЯТЕЛЬНОСТИ ПРЕДПРИЯТИЯ В СИСТЕМЕ ИННОВАЦИОННОГО РАЗВИТИЯ}

В статье рассмотрено и систематизировано категории «прибыль» и «ущерб» с последующим определением сути финансовых результатов. Обосновано, что целью финансовых результатов предприятия является поиск императивов увеличения прибыли, как основного финансового результата деятельности используя инновационные средства в направлении его наращивания.

Тоесть, эффективное управление формированием и использованием финансовых результатов предприятия позволит обеспечить рост благосостояния собственников предприятия как фундаментальной основы финансового менеджмента, проявляется в росте стоимости предприятия и создании прибыльного результата.

Ключевые слова: финансовые результаты, прибыль, убыток, рентабельность, инновационные средства.

Постановка проблеми у загальному вигляді і її зв'язок 3 важливими науковими та практичними завданнями. В умовах ринкової економіки обгрунтованість та дієвість управлінських рішень на всіх рівнях значною мірою залежить від фінансових результатів діяльності суб' єктів господарювання, потенційні можливості яких визначаються обсягом ресурсів в напрямку одержання майбутніх економічних вигод. 
Економічні науки: збірник наукових праџь Луцького національного технічного університету. - Серія "Регіональна економіка". - Випуск 15 (59). - Редкол.: відп. ред. д.е.н., професор Л.Л. Ковальська. - Луцьк: ІВВ Луцького НТУ, 2018. - 292 с.

На сьогодні нестабільність економічного середовища вимагає від кожного підприємства пошуку шляхів підвищення ефективності своєї діяльності, що напряму залежать від інноваційної активності та здатності використовувати новітні технологіi, сучасні методи інтернет-маркетингу, підходити до визначення способів задоволення потреб споживачів.

Тому важливість дослідження обумовлюється як теоретичними, так і прикладними аспектами вирішення цієї проблеми, що потребує подальшого пошуку інноваційних імперативів.

Аналіз останніх досліджень, у яких започатковано вирішення проблеми. Актуальність і важливість теми дослідження в ринкових умовах господарювання обумовили мету та послідовність викладення матеріалу.

Вагомий внесок у розробку теоретичних та методичних засад оцінки фінансових результатів діяльності підприємств внесли вчені-економісти: О.В. Лишиленко, В.Г. Швець, С.В. Мочерний, О.М. Бандурко , К.І. Посилаєва , Г.В. Савицька, I.А. Бланк, I.Ю. Матюшенко, Л.М. Драгун, В.М. Пальцан. Проте результати досліджень не дають повної й комплексної уяви про підвищення фінансових результатів підприємств саме інноваційними засобами в умовах ринкової нестабільності.

Цілі статті. Пошук імперативів покращення фінансових результатів діяльності підприємства в системі інноваційного розвитку.

Виклад основного матеріалу дослідження 3 обгрунтуванням отриманих наукових результатів. Становлення та розвиток в Україні ринкової інфраструктури суттєво змінюють економічне, інформаційне i правове середовище функціонування підприємств, зміст їх фінансової діяльності. За цих умов необхідна сучасна, адекватна ринковій економіці організація фінансової діяльності в напрямку отримання ефективних фінансових результатів.

В організаційній та управлінській роботі підприємств фінансові результати займають важливе місце, що забезпечують своєчасність та повноту фінансової сторони виробничо- 
Економічні науки: збірник наукових праиь Луиького національного технічного університету. - Серія "Регіональна економіка". - Випуск 15 (59). - Редкол.: відп. ред. д.е.н., професор Л.Л. Ковальська. - Луцьк: ІВВ Луцького НТУ, 2018. - 292 с.

господарської діяльності та розвитку підприємства, виконання фінансових зобов'язань перед державою та іншими суб' єктами господарювання.

Адже, реалізація економічної стратегії розвитку підприємства в основному визначається обсягом доходу, який отримується, що виступає джерелом покриття поточних витрат та утворенням прибутку.

Так, під фінансовими результатами діяльності підприємства розуміють приріст або зменшення вартості власного капіталу підприємства, що утворюється в процесі його підприємницької діяльності за звітний період.

Основним фінансовим результатом діяльності підприємства $є$ прибуток, збільшення якого засвідчує примноження фінансових ресурсів та зростання фінансових результатів. Збиток підприємства характеризує втрату фінансових ресурсів, що рівноцінно зменшує фінансовий результат. Тобто фінансововий результат окреслює поняття прибутку та збитку.

У положенні (стандарті) бухгалтерського обліку 3 «Звіт про фінансові результати» надані наступні визначення прибутку та збитку [1]: прибуток - сума, на яку доходи перевищують пов'язані з ними витрати; збиток - перевищення суми витрат над сумою доходу, для отримання якого були здійснені ці витрати.

Відповідно до Закону України «Про бухгалтерський облік та фінансову звітність в Україні» фінансовий результат (прибуток або збиток) повинен визначатися і відображатися в бухгалтерському обліку та фінансовій звітності згідно 3 принципом нарахування та відповідності доходів і витрат [2]. Отже, відповідно до вищезазначеного принципу, 3 метою визначення фінансових результатів звітного періоду необхідно зіставляти доходи звітного періоду 3 витратами, що були здійснені для отримання цих доходів.

Питання теоретичних аспектів визначення фінансових результатів відображені у багатьох наукових працях, що висвітлюють різні погляди на його суть. 

університету. - Серія "Регіональна економіка". - Випуск 15 (59). - Редкол.: відп. ред. д.е.н., професор Л.Л. Ковальська. - Луцьк: ІВВ Луцького НТУ, 2018. - 292 с.

3 метою формування визначення суті фінансових результатів систематизовано категорії «прибуток» та «збиток», що подано в таблиці 1.

В результаті дослідження сутності фінансових результатів виділено характерні особливості двох компонентів: прибутку і збитку, що закладені в дане поняття.

Відтак, під фінансовими результатами діяльності підприємства будемо розуміти кількісний підсумковий показник, джерело господарських засобів, що характеризує співставлення регламентованих законодавствам валових доходів і валових витрат, відображених у формі прибутку або збитку підприємства.

Тобто, прибуток окреслює грошовий результат підприємства після збуту або реалізації товарів, робіт та послуг. Збиток характеризує втрату коштів підприємством під впливом різних факторів та різного роду випадків.

Грунтуючись на запропонованих підходах до оцінки фінансових результатів діяльності підприємства, в систему будемо закладати інноваційні засоби для покращення фінансових результатів та отримання максимально ефективного результату (рис. 1).

В алгоритм покращення фінансових результатів підприємства інноваційними засобами закладаємо використання сучасних методів підняття обізнаності населення щодо виготовлення продукції масового вжитку та просування іiі в точки роздрібної торгівлі. 
Таблиця 1

Визначення суті фінансових результатів підприємства*

\begin{tabular}{|c|c|c|}
\hline Прибуток & Фінансові результати & Збиток \\
\hline $\begin{array}{l}\text { Залишкова сума після вирахування витрат (що } \\
\text { включає коригування збереження капіталу в разі } \\
\text { необхідності) } 3 \text { доходу, а також будь-яка величина, } \\
\text { що перевищує суму, необхідну для збереження } \\
\text { капіталу на початок періоду [4] }\end{array}$ & $\begin{array}{c}\text { Збільшення або зменшення } \\
\text { економічних вигод в } \\
\text { результаті господарської } \\
\text { діяльності }\end{array}$ & $\begin{array}{l}\text { Зменшення економічних вигод, що } \\
\text { за своєю суттю не відрізняється від } \\
\text { інших витрат [4] }\end{array}$ \\
\hline $\begin{array}{l}\text { Джерело господарських засобів і відповідних } \\
\text { резервів, збільшення капіталу в результаті діяльності } \\
\text { та фінансовий результат [2, с. } 14]\end{array}$ & $\begin{array}{l}\text { Джерело господарських } \\
\text { засобів та резервів, } \\
\text { збільшення або зменшення } \\
\text { капіталу }\end{array}$ & $\begin{array}{l}\text { Від’ємна різниця між виручкою і } \\
\text { витратами, нарахованим податком } \\
\text { на прибуток [2, с. } 14]\end{array}$ \\
\hline $\begin{array}{l}\text { Сума коштів, на яку дохід підприємства перевищує } \\
\text { витрати }[5, \text { с. } 57]\end{array}$ & $\begin{array}{c}\text { Сума коштів, на яку дохід } \\
\text { перевищує або не перевищує } \\
\text { витрати }\end{array}$ & $\begin{array}{l}\text { Кошти, які безповоротно витрачені } \\
\text { суб'єктами [5, с. } 368]\end{array}$ \\
\hline
\end{tabular}




\begin{tabular}{|c|c|c|}
\hline \multicolumn{3}{|r|}{ Продовження табл. 1} \\
\hline 1 & 2 & 3 \\
\hline $\begin{array}{l}\text { Перевищення доходів від його діяльності над сумою } \\
\text { видатків; він являє собою єдину форму його власних } \\
\text { нагромаджень. [7, с. 57] }\end{array}$ & $\begin{array}{c}\text { Перевищення доходів або } \\
\text { видатків від його діяльності } \\
\text { над сумою прибутку }\end{array}$ & $\begin{array}{l}\text { Перевищення видатків від його } \\
\text { діяльності над сумою доходів; він } \\
\text { являє собою відсутність власних } \\
\text { нагромаджень в даному періоді }\end{array}$ \\
\hline $\begin{array}{l}\text { Частина вартості додаткового продукту, виражена в } \\
\text { грошах; частина чистого доходу; грошовий вираз } \\
\text { вартості реалізованого чистого доходу, основна } \\
\text { форма грошових накопичень господарського } \\
\text { суб'єкта [8, с. 86] }\end{array}$ & $\begin{array}{c}\text { Характеризує присутність або } \\
\text { відсутність грошових } \\
\text { накопичень господарського } \\
\text { суб'єкта }\end{array}$ & $\begin{array}{l}\text { Характеризує відсутність грошо- } \\
\text { вих накопичень господарського } \\
\text { суб' єкта }\end{array}$ \\
\hline $\begin{array}{l}\text { Частина чистого доходу, створеного в процесі } \\
\text { виробництва та реалізованого в сфері обігу, який } \\
\text { безпосередньо отримують підприємства. [9, с. 263] }\end{array}$ & $\begin{array}{c}\text { Додатній або від’ємний } \\
\text { результат, створений в } \\
\text { процесі виробництва, який } \\
\text { отримують підприємства }\end{array}$ & $\begin{array}{l}\text { Від’ємний результат, створений в } \\
\text { процесі неефективного вироб- } \\
\text { ництва, який отримують } \\
\text { підприємства }\end{array}$ \\
\hline 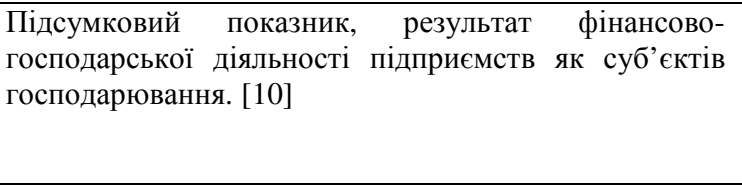 & $\begin{array}{c}\text { Підсумковий показник, } \\
\text { результат фінансово- } \\
\text { господарської діяльності } \\
\text { підприємств }\end{array}$ & $\begin{array}{l}\text { Підсумковий від’ємний показник, } \\
\text { результат } \quad \text { неефективної } \\
\text { фінансово-господарської } \\
\text { діяльності підприємств як } \\
\text { суб'єктів господарювання. }\end{array}$ \\
\hline $\begin{array}{l}\text { Втілений у грошовій формі чистий дохід підприємця } \\
\text { на вкладений капітал, що характеризує його } \\
\text { винагороду за ризик здійснення підприємницької } \\
\text { діяльності та є різницею між сукупним доходом і } \\
\text { сукупними витратами у процесі здійснення } \\
\text { підприємницької діяльності }[11, \text { с. } 8]\end{array}$ & $\begin{array}{c}\text { Втілений у грошовій формі } \\
\text { прибуток (збиток) } \\
\text { підприємця на вкладений } \\
\text { капітал, що характеризує } \\
\text { плату за ризик здійснення } \\
\text { підприємницької діяльності }\end{array}$ & $\begin{array}{l}\text { Втілений у грошовій формі } \\
\text { від’ємний результат підприємця } \\
\text { на вкладений капітал, що } \\
\text { характеризує втрату капіталу за } \\
\text { ризик здійснення } \\
\text { підприємницької діяльності }\end{array}$ \\
\hline
\end{tabular}


Економічні науки: збірник наукових праць Луцького національного технічного університету. - Серія "Регіональна економіка". - Випуск 15 (59). - Редкол.: відп. ред. д.е.н., професор Л.Л. Ковальська. - Луцьк: ІВВ Луцького НТУ, 2018. - 292 с.

Отже, фінансові результати суб'єктів господарювання відображають ефективність господарювання підприємства за всіма напрямами його діяльності: виробничою, збутовою, постачальницькою, фінансовою i інвестиційною, вони становлять основу економічного розвитку підприємства i зміцнення його фінансових відносин з партнерами.

Зростання фінансового результату створює фінансову основу для самофінансування діяльності підприємства, здійснюючи розширене відтворення. Фінансовий результат господарювання підприємства, що виступає у формі прибутку або збитку, відображає ефективність його операційної, фінансової, інвестиційної діяльності та служить основним критерієм стратегії суб'єкта господарювання [12, с. 111].

Висновки. Узагальнюючи все вищесказане, відмітимо що фінансовим результатом є прибуток або збиток. Фінансові результати сприяють діловій активності підприємств у фінансовій та виробничій сфері, що в кінцевому результаті зміцнює бюджет держави. Тобто ефективне управління формуванням та використанням фінансових результатів підприємства дасть змогу забезпечити зростання достатку власників підприємства як фундаментальної основи фінансового менеджменту, що проявляється у зростанні вартості підприємства та створенні прибуткового результату.

Реалізація зазначених заходів в напрямку покращення фінансових результатів діяльності інноваційними засобами дозволить підприємству отримати економічний ефект зростання валового доходу.

Слід зазначити, що весь приріст валового доходу від впровадження запропонованих заходів i частину власних ресурсів підприємства пропонується використовувати на створення єдиної служби маркетингу. Однак найбільш істотним результатом впровадження зазначених заходів варто вважати загальне зростання конкурентоспроможності та зміцнення конкурентних позицій на ринку, отримане в результаті правильного підходу до організації та проведення фінансовогосподарської діяльності підприємства. 
Економічні науки: збірник наукових праць Луцького національного технічного університету. - Серія “Регіональна економіка". - Випуск 15 (59). - Редкол.: відп. ред. д.е.н., професор Л.Л. Ковальська. - Луцььк: ІВВ Луцьького НТУ, 2018. - 292 с.

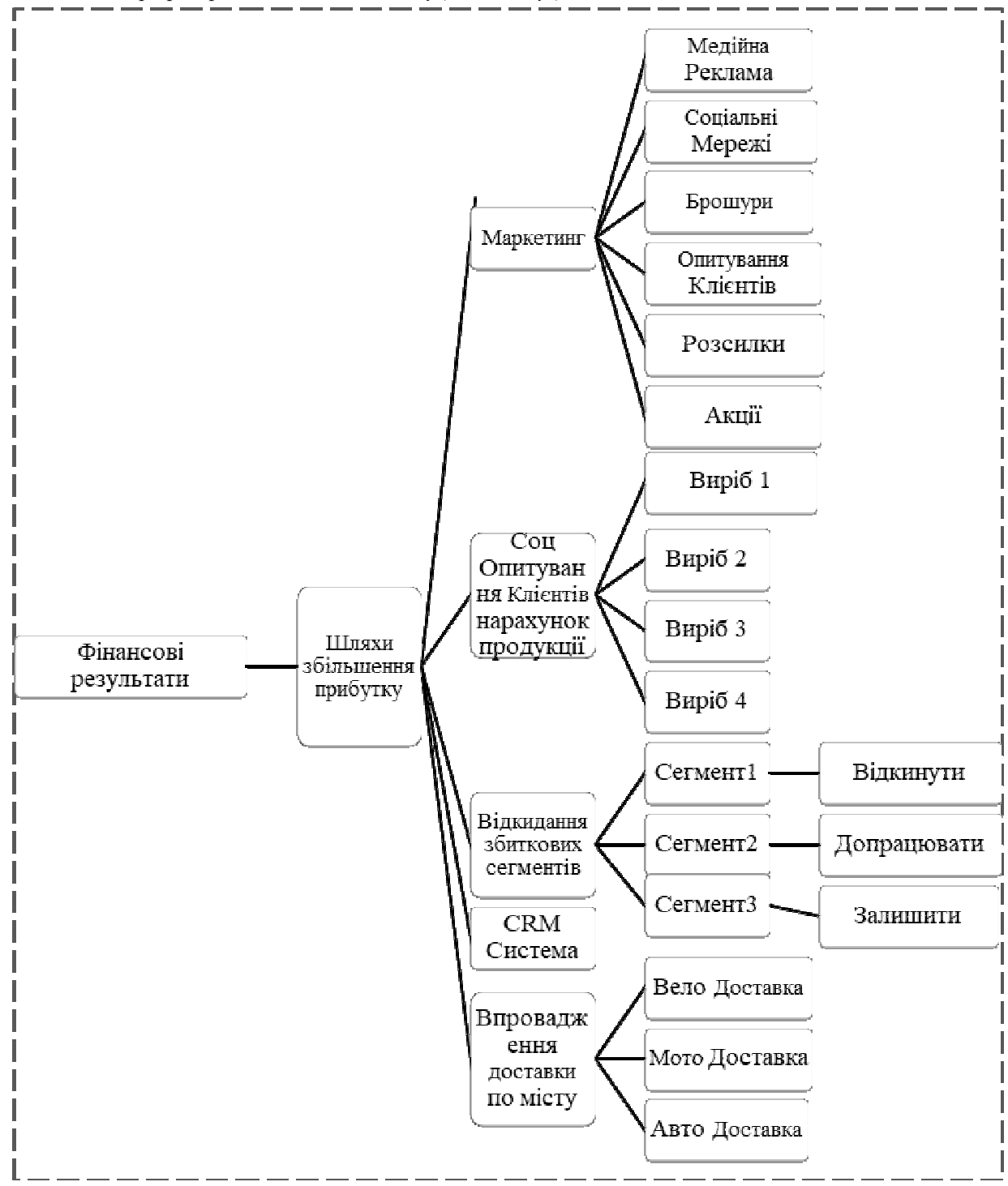

Рис. 1. Алгоритм покращення фінансових результатів підприємства інноваційними засобами 
Економічні науки: збірник наукових праць Луцького національного технічного університету. - Серія "Регіональна економіка". - Випуск 15 (59). - Редкол.: відп. ред. д.е.н., професор Л.Л. Ковальська. - Луиьк: ІВВ Луиького НТУ, 2018. - 292 с.

1. Драгун Л.М. Удосконалення аналізу ефективності використання обігових коштів підприємства / Л.М. Драгун, В.Ф. Левченко, О.Л. Бондаренко // Фінанси України. - 1998. - №12 - С. 12-20.

2. Кривов'язюк I.В. Економічна діагностика: навч. посіб. / I.В. Кривов’ язюк. - К.: Центр навчальної літератури, 2013. - 450 с.

3. Положення (стандарт) бухгалтерського обліку «Звіт про фінансові результати» [Електронний Ресурс] /Міністерство фінансів. - Режим доступу: http://zakon5.rada.gov.ua/laws/show/z0397-99.

4. Герасимчук 3.В. Фінансовий менеджмент: навчальний посібник / 3.В. Герасимчук, I.М. Вахович. - Луцьк: Надстир'я, 2004. - 520 с.

5. Лишиленко О.В. Теорія бухгалтерського обліку: навч. посіб. / О.В. Лишиленко. - К.: Центр навчальної літератури, 2003. - 215 с.

6. Швець В.Г. Теорія бухгалтерського обліку: навч. посіб. / В.Г. Швець. - К.: Знання-Прес, 2003. - 444 с.

7. Економічний енциклопедичний словник: у 2 т. / [С.В. Мочерний, Я.С. Ларіна, О.А. Ксенко, С.І. Юрій]; ред. С.В. Мочерний. - Л.: Світ, 2005. T. $2 .-563 \mathrm{c}$.

8. Економічна енциклопедія: у 3 т. / за ред. С.В. Мочерного та ін. - К.: Академія, 2002. - Т. 2. - 952 с.

9. Фінансова діяльність підприємства / [О.М. Бандурко, М.Я. Коробов, П.І. Орлов, К.Я. Петрова]. - К.: Либідь, 2004. - 310 с.

10. Посилаєва К.І. Підходи визначення прибутку для аналізу ефективності діяльності підприємства / К.І. Посилаєва // Вісн. ХНАУ. Сер. «Економіка АПК і природокористування». - Х., 2008. - № 7. - С. 83-87.

11. Савицкая Г.В. Анализ хозяйственной деятельности предприятия / Г.В. Савицкая. - 4-е изд., перераб. и доп. - Мн.: Новое знание, 2000. - 688 с.

12. Пальцан В.М. Теоретичні дослідження поняття фінансові результати діяльності підприємства / В.М. Пальцман. - Матеріали Міжнародної науково-практичної конференції «Розвиток соціальноекономічних систем в геоекономічному просторі: теорія, методологія, організація обліку та оподаткування» - 11-12 травня. - Тернопіль, 2017. C. 110-112. 